\title{
Pengaruh Jarak Tanam dan Dosis Pupuk Kandang Terhadap Pertumbuhan dan Produksi Tanaman Kubis Bunga Putih (Brassica oleracea var. botrytis L. subvar. cauliflora DC).
}

\section{Effect of Plant Spacing And Dose Chicken Manure on Growth and Production Plant White Flower Cabbage (Brassica oleracea var. Botrytis L. subvar. Cauliflora DC)}

\author{
Hamidah \\ Tenaga Pendidik Program Studi Agroteknologi, Fakultas Pertanian, Universitas Widya Gama Mahakam \\ Jl. KH. Wahid Hasyim, Sempaja, Samarinda, Kalimantan Timur, Indonesia. \\ email : hamidah_ardani@yahoo.co.id
}

Diterima : 2 Agustus 2012 Disetujui : 4 September 2012

\begin{abstract}
Dose Effect of Plant Spacing and Manure on Growth and Production of White Flower Cabbage (Brassica oleracea var. Botrytis L. subvar. Cauliflora DC). Under the guidance of Rustam baraq Noor and Hamida. Order to determine the effect of plant spacing and doses of manure and interaction on the growth and yield of the White Flower Cabbage (Brassica oleracea var. Botrytis L. subvar. Cauliflora DC). Research carried out for 4 months, from the month from June to September 2011. The study was conducted in land practices Bapeltan UPTB Sempaja Samarinda. Research arranged in a randomized block design $(R B D)$ with $3 \times 4$ factorial analysis and repeated 3 times. The first factor is the spacing of $(K)$, which consists of three levels, namely: $\mathrm{kl}$ (spacing of $60 \mathrm{~cm} \times 50 \mathrm{~cm}$ ), $\mathrm{k} 2$ (spacing of $60 \mathrm{~cm}$ $\times 60 \mathrm{~cm})$ and $\mathrm{k} 3$ (spacing of $60 \mathrm{~cm} \times 70 \mathrm{~cm})$. The second factor is the dose of chicken manure (F) which consists of 4 levels, namely: fo (Control), $f 1$ (1.5 kg dose of chicken manure / $\mathrm{m} 2$ ), $f 2$ (dose $2.0 \mathrm{~kg}$ chicken manure / $\mathrm{m} 2$ and f3 (dose $2.5 \mathrm{~kg}$ chicken manure / m2). The results showed the best treatment plant spacing on $\mathrm{k} 2$ (spacing of $60 \mathrm{~cm} \times 60 \mathrm{~cm}$ ). The treatment dose of the best chicken manure on $\mathrm{f2}$ (dose $2.0 \mathrm{~kg}$ chicken manure / $\mathrm{m} 2$ ). The combination of treatment and dose spacing of the best chicken manure on $k 2 f 2$ ( (spacing of $60 \mathrm{~cm} \times 60 \mathrm{~cm}) ;($ dose $2.0 \mathrm{~kg}$ of chicken manure ) $m 2)\}$.
\end{abstract}

Keywords: plant spacing, fertilizer and cabbage white flowers.

\section{PENDAHULUAN}

Kubis Bunga Putih merupakan jenis Kubis yang mempunyai nilai ekonomi yang tinggi dibanding jenis sayuran lain. Walaupun tanaman ini bukan tanaman asli Indonesia tapi jenis sayuran ini sudah sangat populer karena masyarakat Indonesia gemar mengkonsumsi sayur-sayuran. Menurut Dinas Pertanian Tanaman Pangan Samarinda (2008) pada tahun 2007 rata-rata produksi Kubis Bunga Putih dengan luas areal panen 39 ha tingkat produktivitasnya 0,62 ton/ha dengan total produksi sebesar 29 ton. Hal ini memperlihatkan produksi Kubis Bunga Putih di Kalimantan Timur masih rendah dikarenakan masih adanya anggapan tanaman ini memerlukan suhu rendah dan lebih cocok ditanam di dataran tinggi. Namun sekarang ini banyak bermunculan varietas Kubis Bunga Putih yang dapat ditanam pada dataran rendah dengan hasil produksi yang baik. Varietas Kubis Bunga Puth yang dapat ditanam pada dataran rendah satu diantaranya adalah PM 126 F1 yang diproduksi oleh PT. East West Seed Indonesia dengan merk dagang cap Panah Merah. Benih yang berkualitas diperlukan untuk meningkatkan

produksi namun perlu didukung dengan perawatan yang tepat termasuk pemupukan yang tepat sesuai dengan kondisi tanahnya. Penggunaan pupuk kandang ayam yang merupakan pupuk organik dapat memperbaiki kondisi tanah yang kurang subur. Menurut Syekhfani (2000) bahwa pupuk kandang memiliki sifat yang alami dan tidak merusak tanah, menyediakan unsur makro (nitrogen, fosfor, kalium, kalsium, dan belerang) dan mikro (besi, seng, boron, kobalt, dan molibdenium). Selain itu pupuk kandang berfungsi untuk meningkatkan daya menahan air, aktivitas mikrobiologi tanah, nilai kapasitas tukar kation dan memperbaiki struktur tanah. Menurut Setiawan (2002) pengaruh pemberian pupuk kandang secara tidak langsung memudahkan tanah untuk menyerap air. Selain pemberian pupuk kandang ayam, salah satu alternatif untuk meningkatkan hasil tanaman persatuan luas adalah meningkatkan populasi tanaman hingga batas optimum yaitu dengan jalan pengaturan jarak tanam, dimana tindakan ini merupakan salah satu teknik budidaya yang dapat digunakan untuk meningkatkan produksi. Sitompul dan Guritno (1995) menyatakan bahwa pengaturan tanaman di lapangan juga merupakan salah satu faktor yang menentukan keragaman pertumbuhan tanaman. Berdasarkan uraian latar belakang tersebut maka perlu dilakukan penelitian mengenai pengaruh jarak tanam dan dosis pupuk kandang ayam terhadap pertumbuhan dan produksi tanaman Kubis Bunga Putih (Brassica oleracea var. botrytis L. subvar. cauliflora DC) yang diharapkan dengan mengatur jarak tanam dan pemberian pupuk dapat meningkatkan produksi per luasan area. 


\section{BAHAN DAN METODE}

Penelitian ini dilaksanakan selama 4 (empat) bulan, yaitu dari bulan Juni sampai September 2011. Tempat penelitian dilaksanakan di lahan praktik UPTB Bapeltan Sempaja Samarinda. Bahan yang digunakan dalam penelitian ini adalah : Benih kubis bunga putih varietas PM $126 \mathrm{~F}^{\circledR}{ }^{\circledR}$, pupuk kandang ayam, kapur dolomit, topsoil, herbisida Gramaxone, insektisida dan nematisida Furadan 3G, insektisida Curacron 500EC, insektisida Proclim, insektisida Prevanton, fungisida Bion M, fungisida Armstrop, fungisida Antracol, air. Penelitian menggunakan Rancangan Acak Kelompok (RAK) dengan analisis faktorial 3 x 4 dan diulang sebanyak 3 kali. Faktor pertama adalah jarak tanam $(\mathrm{K})$ yang terdiri dari 3 taraf yaitu $\left(\mathrm{k}_{1}\right.$ : Jarak tanam $60 \mathrm{~cm}$ x $50 \mathrm{~cm}, \mathrm{k}_{2}$ : Jarak tanam $60 \mathrm{~cm}$ x $60 \mathrm{~cm}$ dan $\mathrm{k}_{3}$ : Jarak tanam $60 \mathrm{~cm}$ x $70 \mathrm{~cm}$ ) dan faktor kedua adalah dosis pupuk kandang ayam $(\mathrm{F})$ yang terdiri dari 4 taraf, yaitu : $\mathrm{f}_{0}$ : Kontrol, $\mathrm{f}_{1}$ : Dosis $1,5 \mathrm{~kg}$ pupuk kandang ayam $/ \mathrm{m}^{2}$ lahan setara dengan 15 ton/ha, $\mathrm{f}_{2}$ : Dosis $2,0 \mathrm{~kg}$ pupuk kandang ayam $/ \mathrm{m}^{2}$ lahan setara dengan 20 ton/ha dan $\mathrm{f}_{3}$ : Dosis $2,5 \mathrm{~kg}$ pupuk kandang ayam $/ \mathrm{m}^{2}$ lahan setara dengan 25 ton/ha. Pelaksanaan penelitian Persiapan tempat penelitian berukuran $8 \times 75$ m dibersihkan dengan cangkul dari kotoran dan gulma. Kemudian dibuat bedengan dengan ukuran $100 \mathrm{~cm}$ x $500 \mathrm{~cm}$ x $30 \mathrm{~cm}$ dan jarak antar bedengan adalah $80 \mathrm{~cm}$ sedangkan jarak antar kelompok adalah $100 \mathrm{~cm}$, persiapan media semai tanah yang digunakan sebagai media semai adalah tanah lapisan atas (topsoil) dan pupuk kandang ayam dengan perbandingan 2:1. Tanah yang akan digunakan terlebih dahulu dibersihkan dari kotoran dan gulma, digemburkan dan dikeringanginkan. Media semai dicampur merata dan diberi Furadan 3G dengan dosis $10 \mathrm{~g}$ untuk tiap 1 karung pupuk kandang ayam yang dicampur dengan 2 karung topsoil. Media semai yang telah disiapkan kemudian dimasukkan ke dalam potray, kemudian disusun dalam shading house. Kemudian dibuat lubang semai pada tiap potray dengan menggunakan tugal sedalam $0,5 \mathrm{~cm}$ untuk lubang penyemaian benih kubis bunga putih, penyemaian benih kubis bunga putih benih kubis bunga putih berisi sekitar 1.750 benih / pack dengan berat sekitar 10 g/pack. Kemasan benih dibuka kemudian tiap lubang potray ditanam 1 benih. Kemudian lubang tanam yang telah diisi benih ditutup dengan tanah halus. Untuk pemeliharaan dilakukan dengan penyiraman sebanyak 2 kali dengan menggunakan gembor pada pagi dan sore hari. Penyemaian benih dilakukan selama 3-4 minggu hingga bibit memiliki daun sebanyak 5-6 helai dan siap untuk dipindah tanam, perlakuan dosis pupuk kandang ayam ditimbang dengan menggunakan timbangan dengan berat $7,5 \mathrm{~kg}$,
$10,0 \mathrm{~kg}$ dan 12,5 $\mathrm{kg}$ kemudian dimasukkan ke dalam karung. Dibutuhkan sebanyak 12 karung untuk masing-masing berat perlakuan jadi terdapat 36 karung. Bedengan yang telah disiapkan dengan ukuran $100 \mathrm{~cm}$ x $500 \mathrm{~cm}$ x $30 \mathrm{~cm}$ ditaburi dolomit dengan dosis $0,5 \mathrm{~kg} / \mathrm{m}^{2}$ kemudian dicangkul hingga tercampur merata dan dibiarkan selama 1 minggu. Setelah 1 minggu kemudian diberikan perlakuan pupuk kandang ayam dengan dosis sesuai dengan perlakuan. Pemberian dilakukan dengan cara menaburkan pupuk kandang ayam di atas bedengan kemudian dicangkul hingga tercampur secara merata. Bedengan yang telah diberi perlakuan kemudian ditaburi Furadan $3 \mathrm{G}$ dengan dosis $2 \mathrm{~g} / \mathrm{m}^{2}$. Bedengan kemudian ditutup mulsa PHP dan dibiarkan selama 2 minggu, perlakuan jarak tanam dilakukan dengan cara mengatur jarak tanam bibit kubis bunga putih di atas bedengan. Pengaturan jarak tanam menggunakan tali yang telah diberi tanda untuk tiap jarak tanam sesuai perlakuan. Kemudian mulsa PHP dilubangi dengan menggunakan alat pelubang mulsa sesuai dengan jarak tanamnya. Jarak tanam antar barisan adalah $60 \mathrm{~cm}$ dimana tiap bedengan terdapat 2 barisan. Sedangkan jarak tanam dalam barisan sesuai perlakuan yaitu $50 \mathrm{~cm}, 60 \mathrm{~cm}$ dan $70 \mathrm{~cm}$, penanaman bibit kubis bunga putih setelah perlakuan jarak tanam dengan melubangi mulsa PHP dilakukan penanaman bibit kubis bunga putih. Bibit yang akan ditanam sudah memiliki 5 - 6 helai daun atau berumur 3 minggu setelah semai. Penanaman dilakukan dengan cara membuat lubang tanam tepat di tengah lubang mulsa sedalam $10 \mathrm{~cm}$. Bibit kubis bunga putih ditanam pada lubang tanam. Bibit yang telah ditanam kemudian ditutup dengan gelas plastik air mineral yang telah dilubangi bagian bawahnya dan diletakkan dengan posisi terbalik untuk melindungi bibit dari serangan hama, pemeliharaan tanaman meliputi : penyiraman, penyiangan dan pengendalian hama dan penyakit dan panen kubis bunga putih dilakukan sekitar 45 hari setelah tanam atau sekitar 75 hari setelah semai. Panen dapat dilakukan jika crop kubis bunga putih telah tampak berbentuk bulatanbulatan pada permukaan crop sehingga permukaan crop tampak tidak halus/licin dan permukaan crop telah mulai tampak pecah-pecah. Pemanenan dilakukan dengan memotong pangkal crop dengan menggunakan gunting setek. Pengambilan data meliputi ; pertambahan jumlah daun jumlah daun pada umur 15, 30 dan 45 HST, pertambahan tinggi tanaman pada umur 15,30 dan 45 HST, pertambahan diameter tajuk tanaman pada umur 15, 30 dan 45 HST, saat munculnya crop, Berat basah crop dan Data primer berupa hasil pengolahan data dari pengukuran dan penghitungan parameter pertumbuhan yang terdiri dari pertambahan jumlah daun (helai), 
pertambahan tinggi tanaman $(\mathrm{cm})$, pertambahan diameter tajuk $(\mathrm{cm})$ serta parameter produksi yang terdiri dari saat munculnya crop (HST) dan berat basah crop $(\mathrm{kg})$. Data dianalisis dengan menggunakan sidik ragam, apabila terdapat pengaruh pada sidik ragam maka dilakukan uji
BNT pada taraf 5\% dan data sekunder berupa data iklim dari stasiun klimatologi Temindung Samarinda yang terdiri dari data curah hujan, temperatur, intensitas penyinaran dan kelembapan dari bulan Juni sampai dengan September 2012.

\section{HASIL DAN PEMBAHASAN}

\section{Pengaruh Perlakuan Jarak Tanam Terhadap Pertumbuhan dan Produksi Tanaman Kubis Bunga Putih}

Tabel 1. Rata-Rata Pertambahan Jumlah Daun pada Perlakuan Jarak Tanam

\begin{tabular}{cccc}
\hline Perlakuan Jarak & \multicolumn{3}{c}{ Rata-rata pertambahan jumlah daun (helai) } \\
\cline { 2 - 4 } Tanam & 15 HST & 30 HST & 45 HST \\
\hline $\mathrm{k}_{1}$ & $4,15^{\mathrm{b}}$ & $7,90^{\mathrm{c}}$ & 12,29 \\
$\mathrm{k}_{2}$ & $4,52^{\mathrm{a}}$ & $10,67^{\mathrm{a}}$ & 12,48 \\
$\mathrm{~K}_{3}$ & $4,40^{\mathrm{a}}$ & $9,67^{\mathrm{b}}$ & 12,54 \\
\hline
\end{tabular}

Keterangan : Angka-angka yang diikuti huruf yang sama menunjukkan tidak berbeda nyata berdasarkan uji BNT pada taraf $\alpha=5 \%$

Tabel 2. Rata-Rata Pertambahan Tinggi Tanaman pada Perlakuan Jarak Tanam

\begin{tabular}{cccc}
\hline \multirow{2}{*}{$\begin{array}{c}\text { Perlakuan Jarak } \\
\text { Tanam }\end{array}$} & \multicolumn{3}{c}{ Rata-rata pertambahan tinggi tanaman $(\mathrm{cm})$} \\
\cline { 2 - 4 } & $15 \mathrm{HST}$ & $30 \mathrm{HST}$ & $45 \mathrm{HST}$ \\
\hline $\mathrm{k}_{1}$ & 3,86 & $5,30^{\mathrm{ab}}$ & $10,56^{\mathrm{a}}$ \\
$\mathrm{k}_{2}$ & 3,78 & $5,64^{\mathrm{a}}$ & $5,64^{\mathrm{a}}$ \\
$\mathrm{K}_{3}$ & 3,78 & $4,85^{\mathrm{b}}$ & $4,85^{\mathrm{b}}$ \\
\hline
\end{tabular}

Keterangan : Angka-angka yang diikuti huruf yang sama menunjukkan tidak berbeda nyata berdasarkan uji BNT pada taraf $\alpha=5 \%$

Tabel 3. Rata-Rata Pertambahan Diameter Tajuk Tanaman pada Perlakuan Jarak Tanam

\begin{tabular}{cccc}
\hline Perlakuan & \multicolumn{3}{c}{ Rata-rata pertambahan diameter tajuk tanaman $(\mathrm{cm})$} \\
\cline { 2 - 4 } Hormon & $15 \mathrm{HST}$ & $30 \mathrm{HST}$ & $45 \mathrm{HST}$ \\
\hline $\mathrm{k}_{1}$ & $14,13^{\mathrm{b}}$ & $37,11^{\mathrm{b}}$ & $38,65^{\mathrm{b}}$ \\
$\mathrm{k}_{2}$ & $20,52^{\mathrm{a}}$ & $47,81^{\mathrm{a}}$ & $48,25^{\mathrm{a}}$ \\
$\mathrm{K}_{3}$ & $20,75^{\mathrm{a}}$ & $48,14^{\mathrm{a}}$ & $48,56^{\mathrm{a}}$ \\
\hline
\end{tabular}

Keterangan : Angka-angka yang diikuti huruf yang sama menunjukkan tidak berbeda nyata berdasarkan uji BNT pada taraf $\alpha=5 \%$

Tabel 4. Rata-Rata Saat Munculnya Crops pada Perlakuan Jarak Tanam

\begin{tabular}{cc}
\hline Perlakuan & Rata-rata saat munculnya Crops(hst) \\
Hormon & $22,60^{\mathrm{b}}$ \\
\hline $\mathrm{k}_{1}$ & $22,35^{\mathrm{a}}$ \\
$\mathrm{k}_{2}$ & $22,33^{\mathrm{a}}$ \\
$\mathrm{K}_{3}$ & \\
\hline
\end{tabular}

Keterangan : Angka-angka yang diikuti huruf yang sama menunjukkan tidak berbeda nyata berdasarkan uji BNT pada taraf $\alpha=5 \%$

Tabel 5. Rata-Rata Berat Crops Basah pada Perlakuan Jarak Tanam

\begin{tabular}{cc}
\hline Perlakuan & Rata-rata berat crops basah $(\mathrm{kg})$ \\
Hormon & $0,79^{\mathrm{b}}$ \\
$\mathrm{k}_{1}$ & $0,84^{\mathrm{b}}$ \\
$\mathrm{k}_{2}$ & $0,89^{\mathrm{a}}$ \\
$\mathrm{K}_{3}$ & \\
\hline
\end{tabular}

Keterangan : Angka-angka yang diikuti huruf yang sama menunjukkan tidak berbeda nyata berdasarkan uji BNT pada taraf $\alpha=5 \%$ 
Hasil sidik ragam menunjukan bahwa perlakuan jarak tanam berpengaruh sangat nyata terhadap pertambahan jumlah daun umur 15 dan 30 HST, pertambahan diameter tajuk tanaman umur 15, 30 dan 45 HST, saat munculnya crops serta berat basah crops. Perlakuan jarak tanam berpengaruh nyata terhadap pertambahan tinggi tanaman umur 30 dan 45 HST namun perlakuan jarak tanam tidak berpengaruh nyata terhadap pertambahan jumlah daun umur 45 HST dan pertambahan tinggi tanaman umur 15 HST. Hasil uji BNT 5\% menunjukan bahwa perlakuan $\mathrm{k}_{2}$ (Jarak tanam $60 \mathrm{~cm} \times 60 \mathrm{~cm}$ ) tidak berbeda nyata dengan perlakuan $\mathrm{k}_{3}$ (Jarak tanam $60 \mathrm{~cm}$ x $70 \mathrm{~cm}$ ) untuk parameter pertambahan diameter tajuk tanaman, saat munculnya crops serta pertambahan jumlah daun umur 15 HST. Sedangkan untuk parameter pertambahan tinggi tanaman umur 30 dan 45 HST menunjukan bahwa perlakuan $\mathrm{k}_{1}$ (Jarak tanam $60 \mathrm{~cm}$ x $50 \mathrm{~cm}$ ) tidak berbeda nyata dengan perlakuan $\mathrm{k}_{2}$ dan untuk parameter berat basah crops menunjukkan bahwa perlakuan $\mathrm{k}_{3}$ berbeda nyata dengan perlakuan lainnya. Perlakuan terbaik pada $\mathrm{k}_{2}$ untuk parameter pertambahan jumlah daun dengan rata-rata berturut - turut adalah 20,75 cm (15 HST), 48,14 cm (30 HST) dan 48,58 cm (45 HST). Demikian pula untuk parameter saat munculnya crops adalah 22,33 HST serta berat basah crops adalah $0,89 \mathrm{~kg}$. Perlakuan terbaik pada $\mathrm{k}_{1}$ untuk parameter pertambahan tinggi tanaman dengan rata-rata adalah 10,56 cm (45 HST). Perlakuan jarak tanam berpengaruh sangat nyata terhadap parameter pertambahan jumlah daun umur 15 dan 30 HST, pertambahan diameter tajuk tanaman umur 15,30 dan 45 HST, saat munculnya crops serta berat basah crops diduga karena jarak tanam pada perlakuan telah mencukupi untuk memberikan ruang tumbuh yang cukup bagi pertumbuhan dan produksi tanaman kubis bunga putih. Hal ini ditunjukan pada hasil pengamatan pertambahan jumlah daun umur 15 dam 30 HST dimana tanaman masih mengalami fase pertumbuhan vegetatif sehingga dengan adanya ruang tumbuh yang cukup untuk penerimaan sinar matahari pada setiap tanaman serta dengan jarak tanam yang mencukupi untuk pertumbuhan dan perkembangan akar sehingga akar tanaman yang satu tidak dapat memasuki sistem perakaran tanaman yang lainnya yang mengakibatkan penyerapan unsur hara menjadi lebih baik. Hal ini menyebabkan perlakuan jarak tanam berpengaruh sangat nyata terhadap parameter pertambahan jumlah daun umur 15 dan 30 HST yang ditunjukkan dengan hasil pengamatan dimana tanaman yang diberi perlakuan $\mathrm{k}_{3}$ dan $\mathrm{k}_{2}$ memiliki daun yang lebih banyak dibandingkan dengan tanaman yang diberikan perlakuan $\mathrm{k}_{1}$. Hal ini diduga karena dengan jarak tanam sesuai dengan perlakuan $\mathrm{k}_{2}$ dapat membentuk mikroklimat yang sesuai dengan syarat tumbuh tanaman yaitu kisaran temperatur untuk pertumbuhan antara 15 $24^{\circ} \mathrm{C}$ (Harjono, 1996) jika dibandingkan dengan perlakuan $\mathrm{k}_{3}$ yang lebih lebar jarak tanamnya sehingga kelembapannya menjadi lebih rendah yang mengakibatkan temperatur menjadi lebih tinggi jika dibandingkan dengan perlakuan $\mathrm{k}_{2}$ sehingga kurang sesuai dengan syarat tumbuh tanaman. Data dari stasiun Meteorologi Temindung Samarinda menunjukkan bahwa kisaran temperatur selama penelitian antara 27,2 $27,4^{\circ} \mathrm{C}$. Sedangkan pada perlakuan $\mathrm{k}_{1}$ menghasilkan pertambahan jumlah daun yang paling sedikit diduga karena sudah mulai terjadi persaingan dalam penyerapan unsur hara karena sistem perakaran tanaman yang satu sudah mulai memasuki sistem perakaran tanaman yang lain karena jarak tanam yang kurang lebar sehingga terjadi persaingan dalam pemanfaatan unsur hara untuk pertumbuhan tanaman. Namun perlakuan jarak tanam tidak berpengaruh nyata terhadap pertambahan jumlah daun umur $45 \mathrm{HST}$, hal ini diduga karena tanaman telah mengalami fase pertumbuhan generatif yaitu pembentukan crops sehingga pertambahan jumlah daun tidak berbeda nyata antara perlakuan yang satu dengan lainnya. Perlakuan jarak tanam berpengaruh sangat nyata terhadap pertambahan diameter tajuk tanaman dimana perlakuan terbaik pada perlakuan $\mathrm{k}_{3}$ yang diduga dengan jarak tanam yang lebih lebar memberikan ruang tumbuh yang lebih baik terutama dalam pemanfaatan sinar matahari dan unsur hara sehingga pertumbuhan daun tanaman dapat menjadi lebih panjang jika dibandingkan dengan pertumbuhan daun tanaman dengan jarak tanam yang lebih sempit. Perlakuan jarak tanam berpengaruh sangat nyata terhadap saat munculnya crops dimana perlakuan terbaik pada $\mathrm{k}_{2}$. Hal ini diduga karena dengan jarak tanam sesuai dengan perlakuan $\mathrm{k}_{2}$ telah memberikan ruang tumbuh yang mencukupi untuk pertumbuhan yang lebih baik terutama dalam hal pemanfaatan sinar matahari dan penggunaan unsur hara sehingga proses fotosintesa tanaman menjadi lebih baik yang berpengaruh terhadap kecepatan pembentukan bunga. Hal ini ditunjukkan dengan perlakuan jarak tanam yang semakin lebar menghasilkan saat terbentuknya crops yang lebih cepat dibandingkan dengan perlakuan jarak tanam yang lebih sempit. Dengan ruang tumbuh yang lebih luas maka daun tanaman leluasa membuka ke samping sehingga memberikan ruang yang mencukupi untuk pertumbuhan dan perkembangan bunga yang lebih baik. Hal ini ditunjukkan dengan perlakuan $\mathrm{k}_{3}$ menghasilkan berat basah crops yang lebih baik jika dibandingkan dengan perlakuan lainnya Perlakuan jarak tanam tidak berpengaruh nyata terhadap pertambahan tinggi tanaman umur 15 HST diduga karena ruang tumbuh dengan jarak tanam sesuai perlakuan masih mencukupi untuk pertumbuhan tanaman umur 15 HST sehingga 
belum terjadi persaingan dalam pemanfaatan sinar matahari. Namun pada saat tanaman berumur 30 dan 45 HST, perlakuan jarak tanam berpengaruh nyata karena ruang tumbuh tanaman sudah kurang mencukupi untuk pertumbuhan dan perkembangan tanaman sehingga terjadi persaingan dalam pemanfaatan sinar matahari. Hal ini ditunjukkan dari hasil pengamatan dari perlakuan jarak tanam dimana semakin sempit jarak tanam maka semakin tinggi pertambahan tinggi tanamannya. Jarak tanam sangat berpengaruh terhadap pertumbuhan tanaman dan produksinya, hal ini sesuai dengan pendapat Cahyono (2001) yang menyatakan bahwa jarak tanam berpengaruh terhadap penerimaan sinar matahari pada setiap tanaman dan berpengaruh pula terhadap penggunaan zat hara.

\section{Pengaruh Perlakuan Dosis Pupuk Kandang Ayam Terhadap Pertumbuhan dan Produksi Tanaman Kubis Bunga Putih}

Tabel 6. Rata-Rata Pertambahan Jumlah Daun pada Perlakuan Pupuk Kandang Ayam

\begin{tabular}{cccc}
\hline Perlakuan & \multicolumn{3}{c}{ Rata-rata pertambahan jumlah daun (helai) } \\
\cline { 2 - 4 } Pukan Ayam & $15 \mathrm{HST}$ & $30 \mathrm{HST}$ & $45 \mathrm{HST}$ \\
\hline $\mathrm{f}_{0}$ & $2,97^{\mathrm{c}}$ & $6,75^{\mathrm{c}}$ & $10,42^{\mathrm{c}}$ \\
$\mathrm{f}_{1}$ & $4,64^{\mathrm{b}}$ & $9,81^{\mathrm{b}}$ & $12,58^{\mathrm{b}}$ \\
$\mathrm{f}_{2}$ & $5,25^{\mathrm{a}}$ & $11,53^{\mathrm{a}}$ & $13,75^{\mathrm{a}}$ \\
$\mathrm{f}_{3}$ & $4,56^{\mathrm{b}}$ & $9,56^{\mathrm{b}}$ & $13,00^{\mathrm{b}}$ \\
\hline
\end{tabular}

Keterangan : Angka-angka yang diikuti huruf yang sama menunjukkan tidak berbeda nyata berdasarkan uji BNT pada taraf $\alpha=5 \%$

Tabel 7. Rata-Rata Pertambahan Tinggi Tanaman pada Perlakuan Pupuk Kandang Ayam

\begin{tabular}{cccc}
\hline Perlakuan & \multicolumn{3}{c}{ Rata-rata pertambahan tinggi tanaman $(\mathrm{cm})$} \\
\cline { 2 - 4 } Pukan Ayam & $15 \mathrm{HST}$ & $30 \mathrm{HST}$ & $45 \mathrm{HST}$ \\
\hline $\mathrm{f}_{0}$ & $3,16^{\mathrm{b}}$ & $3,78^{\mathrm{c}}$ & $6,44^{\mathrm{c}}$ \\
$\mathrm{f}_{1}$ & $3,87^{\mathrm{a}}$ & $5,54^{\mathrm{b}}$ & $9,45^{\mathrm{b}}$ \\
$\mathrm{f}_{2}$ & $4,11^{\mathrm{a}}$ & $6,46^{\mathrm{a}}$ & $12,99^{\mathrm{a}}$ \\
$\mathrm{f}_{3}$ & $4,08^{\mathrm{a}}$ & $5,27^{\mathrm{b}}$ & $10,31^{\mathrm{b}}$ \\
\hline
\end{tabular}

Keterangan : Angka-angka yang diikuti huruf yang sama menunjukkan tidak berbeda nyata berdasarkan uji BNT pada taraf $\alpha=5 \%$

Tabel 8. Rata-Rata Pertambahan Diameter Tajuk Tanaman pada Perlakuan Pupuk Kandang Ayam

\begin{tabular}{cccc}
\hline Perlakuan & \multicolumn{3}{c}{ Rata-rata pertambahan diameter tajuk tanaman $(\mathrm{cm})$} \\
\cline { 2 - 4 } Pukan Ayam & $15 \mathrm{HST}$ & $30 \mathrm{HST}$ & $45 \mathrm{HST}$ \\
\hline $\mathrm{f}_{0}$ & $15,72^{\mathrm{c}}$ & $38,44^{\mathrm{d}}$ & $38,81^{\mathrm{d}}$ \\
$\mathrm{f}_{1}$ & $17,16^{\mathrm{b}}$ & $41,43^{\mathrm{c}}$ & $41,83^{\mathrm{c}}$ \\
$\mathrm{f}_{2}$ & $22,93^{\mathrm{a}}$ & $53,37^{\mathrm{a}}$ & $53,43^{\mathrm{a}}$ \\
$\mathrm{f}_{3}$ & $18,06^{\mathrm{b}}$ & $44,18^{\mathrm{b}}$ & $46,54^{\mathrm{b}}$ \\
\hline
\end{tabular}

Keterangan : Angka-angka yang diikuti huruf yang sama menunjukkan tidak berbeda nyata berdasarkan uji BNT pada taraf $\alpha=5 \%$

Tabel 9. Rata-Rata Saat Munculnya Crops pada Perlakuan Pupuk Kandang Ayam

\begin{tabular}{cc}
\hline Perlakuan & Rata-rata saat munculnya Crops (hst) \\
Pukan Ayam & $23,33^{\mathrm{b}}$ \\
\hline $\mathrm{f}_{0}$ & $22,33^{\mathrm{a}}$ \\
$\mathrm{f}_{1}$ & $22,06^{\mathrm{a}}$ \\
$\mathrm{f}_{2}$ & $22,00^{\mathrm{a}}$ \\
$\mathrm{f}_{3}$ & $22, \mathrm{k}$ \\
\hline
\end{tabular}

Keterangan : Angka-angka yang diikuti huruf yang sama menunjukkan tidak berbeda nyata berdasarkan uji BNT pada taraf $\alpha=5 \%$ 
Tabel 10. Rata-Rata Berat Basah Crops pada Perlakuan Jarak Tanam

\begin{tabular}{cc}
\hline $\begin{array}{c}\text { Perlakuan } \\
\text { Hormon }\end{array}$ & Rata-rata berat basah crops $(\mathrm{kg})$ \\
\hline $\mathrm{f}_{0}$ & $0,69^{\mathrm{d}}$ \\
$\mathrm{f}_{1}$ & $0,81^{\mathrm{c}}$ \\
$\mathrm{f}_{2}$ & $0,97^{\mathrm{a}}$ \\
$\mathrm{f}_{3}$ & $0,90^{\mathrm{b}}$ \\
\hline Keteran &
\end{tabular}

Keterangan : Angka-angka yang diikuti huruf yang sama menunjukkan tidak berbeda nyata berdasarkan uji BNT pada taraf $\alpha=5 \%$

Hasil sidik ragam menunjukan bahwa perlakuan dosis pupuk kandang ayam berpengaruh sangat nyata terhadap semua parameter yang diamati. Hasil uji BNT 5\% menunjukan bahwa perlakuan $\mathrm{f}_{2}$ (Dosis $2,0 \mathrm{~kg}$ pupuk kandang ayam / $\mathrm{m}^{2}$ lahan setara dengan 20 ton/ha) menghasilkan pertumbuhan dan produksi tanaman yang terbaik jika dibandingkan dengan perlakuan $\mathrm{f}_{0}$ (Kontrol), $\mathrm{f}_{1}$ (Dosis $1,5 \mathrm{~kg}$ pupuk kandang ayam $/ \mathrm{m}^{2}$ lahan setara dengan 15 ton/ha), dan $\mathrm{f}_{3}$ (Dosis 2,5 kg pupuk kandang ayam $/ \mathrm{m}^{2}$ lahan setara dengan 25 ton/ha). Hal ini diduga bahwa dengan dosis perlakuan $\mathrm{f}_{2}$ telah mampu menyediakan unsur hara bagi tanaman dalam jumlah yang cukup dan seimbang. Hal ini sesuai dengan pendapat Islami dan Utomo (1995), agar tanaman dapat tumbuh dengan baik diperlukan unsur hara dan air yang cukup dan seimbang. Unsur hara yang berlebihan sangat merugikan karena bukan saja kondisi yang mubajir tetapi juga dapat menghambat pertumbuhan tanaman akibat terhambatnya ketersediaan unsur hara lain / terjadinya keracunan tanaman. Menurut Lingga (1991), suatu tanaman akan tumbuh subur bila elemen yang tersedia cukup dan sesuai dengan kebutuhan tanaman, penambahan unsur hara yang berlebihan tidak menghasilkan pertumbuhan vegetatif maupun generatif yang sebanding dengan unsur hara yang diberikan. Kemudian diperjelas oleh Sutedjo (1991), bahwa apa yang terdapat dalam tubuh tanaman sangat berhubungan dengan pertumbuhannya. Selanjutnya dikatakan bahwa pertumbuhan tanaman akan berlangsung baik apabila kadar unsur hara yang terkandung dalam tanah tempat tumbuhnya masih baik.

\section{Pengaruh Kombinasi Perlakuan Jarak Tanam dan Dosis Pupuk Kandang Ayam Terhadap Pertumbuhan dan Produksi Tanaman Kubis Bunga Putih}

Tabel 11. Rata-Rata Pertambahan Jumlah Daun pada Kombinasi Jarak Tanam dan Perlakuan Pupuk Kandang Ayam

\begin{tabular}{cccc}
\hline Kombinasi & \multicolumn{3}{c}{ Rata-rata pertambahan jumlah daun (helai) } \\
\cline { 2 - 4 } Perlakuan & $15 \mathrm{HST}$ & $30 \mathrm{HST}$ & $45 \mathrm{HST}$ \\
\hline $\mathrm{k}_{1} \mathrm{f}_{0}$ & $2,92^{\mathrm{g}}$ & $6,17^{\mathrm{h}}$ & $12,25^{\mathrm{cd}}$ \\
$\mathrm{k}_{1} \mathrm{f}_{1}$ & $4,75^{\mathrm{c}}$ & $8,00^{\mathrm{ef}}$ & $12,25^{\mathrm{cd}}$ \\
$\mathrm{k}_{1} \mathrm{f}_{2}$ & $4,33^{\mathrm{de}}$ & $9,25^{\mathrm{d}}$ & $11,42^{\mathrm{de}}$ \\
$\mathrm{k}_{\mathrm{f}} \mathrm{f}_{3}$ & $4,58^{\mathrm{cd}}$ & $8,17^{\mathrm{e}}$ & $13,25^{\mathrm{bc}}$ \\
$\mathrm{k}_{2} \mathrm{f}_{0}$ & $3,42^{\mathrm{f}}$ & $7,17^{\mathrm{fg}}$ & $8,33^{\mathrm{f}}$ \\
$\mathrm{k}_{2} \mathrm{f}_{1}$ & $4,00^{\mathrm{e}}$ & $10,58^{\mathrm{c}}$ & $11,92^{\mathrm{d}}$ \\
$\mathrm{k}_{2} \mathrm{f}_{2}$ & $5,92^{\mathrm{a}}$ & $13,67^{\mathrm{a}}$ & $16,25^{\mathrm{a}}$ \\
$\mathrm{k}_{2} \mathrm{f}_{3}$ & $4,75^{\mathrm{c}}$ & $11,25^{\mathrm{bc}}$ & $13,42^{\mathrm{bc}}$ \\
$\mathrm{k}_{3} \mathrm{f}_{0}$ & $2,58^{\mathrm{g}}$ & $6,92^{\mathrm{gh}}$ & $10,67^{\mathrm{e}}$ \\
$\mathrm{k}_{3} \mathrm{f}_{1}$ & $5,17^{\mathrm{b}}$ & $10,83^{\mathrm{bc}}$ & $13,58^{\mathrm{b}}$ \\
$\mathrm{k}_{3} \mathrm{f}_{2}$ & $5,50^{\mathrm{b}}$ & $11,67^{\mathrm{b}}$ & $13,58^{\mathrm{b}}$ \\
$\mathrm{k}_{3} \mathrm{f}_{3}$ & $4,33^{\mathrm{de}}$ & $9,25^{\mathrm{d}}$ & $12,33^{\mathrm{cd}}$ \\
\hline
\end{tabular}

Keterangan : Angka-angka yang diikuti huruf yang sama menunjukkan tidak berbeda nyata berdasarkan uji BNT pada taraf $\alpha=5 \%$ 
Tabel 12. Rata-Rata Pertambahan Tinggi Tanaman pada Perlakuan Kombinasi Jarak Tanam dan Perlakuan Pupuk Kandang Ayam

\begin{tabular}{|c|c|c|c|}
\hline \multirow{2}{*}{$\begin{array}{l}\text { Kombinasi } \\
\text { Perlakuan }\end{array}$} & \multicolumn{3}{|c|}{ Rata-rata pertambahan tinggi tanaman $(\mathrm{cm})$} \\
\hline & 15 HST & $30 \mathrm{HST}$ & $45 \mathrm{HST}$ \\
\hline $\mathrm{k}_{1} \mathrm{f}_{0}$ & $3,17^{\mathrm{de}}$ & $3,80^{\mathrm{de}}$ & $7,80^{\mathrm{efg}}$ \\
\hline $\mathrm{k}_{1} \mathrm{f}_{1}$ & $3,67^{\mathrm{bcd}}$ & $5,07^{\mathrm{bcd}}$ & $9,85^{\text {cde }}$ \\
\hline $\mathrm{k}_{1} \mathrm{f}_{2}$ & $3,97^{\text {abcd }}$ & $6,01^{\mathrm{ab}}$ & $13,39^{\mathrm{ab}}$ \\
\hline $\mathrm{k}_{1} \mathrm{f}_{3}$ & $4,66^{\mathrm{a}}$ & $6,31^{\mathrm{b}}$ & $11,21^{\text {bcd }}$ \\
\hline $\mathrm{k}_{2} \mathrm{f}_{0}$ & $3,58^{\mathrm{bcd}}$ & $4,26^{\mathrm{de}}$ & $6,51^{\mathrm{fg}}$ \\
\hline $\mathrm{k}_{2} \mathrm{f}_{1}$ & $3,90^{\text {abcd }}$ & $5,97^{\mathrm{ab}}$ & $10,16^{\text {cde }}$ \\
\hline $\mathrm{k}_{2} \mathrm{f}_{2}$ & $4,25^{\mathrm{ab}}$ & $7,79^{\mathrm{a}}$ & $15,33^{\mathrm{a}}$ \\
\hline $\mathrm{k}_{2} \mathrm{f}_{3}$ & $3,38^{\text {cde }}$ & $4,54^{\mathrm{cd}}$ & $8,29^{\mathrm{ef}}$ \\
\hline $\mathrm{k}_{3} \mathrm{f}_{0}$ & $2,75^{\mathrm{e}}$ & $3,28^{\mathrm{e}}$ & $5,01^{\mathrm{g}}$ \\
\hline $\mathrm{k}_{3} \mathrm{f}_{1}$ & $4,03^{\mathrm{abc}}$ & $5,57^{\mathrm{abc}}$ & $8,35^{\text {def }}$ \\
\hline $\mathrm{k}_{3} \mathrm{f}_{2}$ & $4,12^{\mathrm{abc}}$ & $5,57^{\mathrm{abc}}$ & $10,24^{\text {cde }}$ \\
\hline $\mathrm{k}_{3} \mathrm{f}_{3}$ & $4,20^{\mathrm{ab}}$ & $4,97^{\text {bcd }}$ & $11,44^{\mathrm{bc}}$ \\
\hline
\end{tabular}

Keterangan : Angka-angka yang diikuti huruf yang sama menunjukkan tidak berbeda nyata berdasarkan uji BNT pada taraf $\alpha=5 \%$

Tabel 13. Rata-Rata Pertambahan Diameter Tajuk Tanaman pada Perlakuan Kombinasi Jarak Tanam dan Perlakuan Pupuk Kandang Ayam

\begin{tabular}{cccc}
\hline Kombinasi & \multicolumn{3}{c}{ Rata-rata pertambahan diameter tajuk tanaman $(\mathrm{cm})$} \\
\cline { 2 - 4 } Perlakuan & $15 \mathrm{HST}$ & $30 \mathrm{HST}$ & $45 \mathrm{HST}$ \\
\hline $\mathrm{k}_{1} \mathrm{f}_{0}$ & $12,53^{\mathrm{f}}$ & $33,73^{\mathrm{e}}$ & $34,13^{\mathrm{e}}$ \\
$\mathrm{k}_{1} \mathrm{f}_{1}$ & $13,34^{\mathrm{f}}$ & $35,06^{\mathrm{de}}$ & $35,61^{\mathrm{de}}$ \\
$\mathrm{k}_{1} \mathrm{f}_{2}$ & $17,06^{\mathrm{de}}$ & $44,04^{\mathrm{c}}$ & $44,04^{\mathrm{c}}$ \\
$\mathrm{k}_{1} \mathrm{f}_{3}$ & $13,60^{\mathrm{f}}$ & $35,60^{\mathrm{de}}$ & $40,80^{\mathrm{de}}$ \\
$\mathrm{k}_{2} \mathrm{f}_{0}$ & $18,05^{\mathrm{cde}}$ & $42,91^{\mathrm{c}}$ & $42,91^{\mathrm{c}}$ \\
$\mathrm{k}_{2} \mathrm{f}_{1}$ & $19,34^{\mathrm{c}}$ & $44,69^{\mathrm{c}}$ & $44,85^{\mathrm{c}}$ \\
$\mathrm{k}_{2} \mathrm{f}_{2}$ & $25,85^{\mathrm{a}}$ & $57,58^{\mathrm{a}}$ & $57,58^{\mathrm{a}}$ \\
$\mathrm{k}_{2} \mathrm{f}_{3}$ & $18,84^{\mathrm{cd}}$ & $46,08^{\mathrm{c}}$ & $47,66^{\mathrm{c}}$ \\
$\mathrm{k}_{3} \mathrm{f}_{0}$ & $16,58^{\mathrm{e}}$ & $38,68^{\mathrm{d}}$ & $39,38^{\mathrm{d}}$ \\
$\mathrm{k}_{3} \mathrm{f}_{1}$ & $18,81^{\mathrm{cd}}$ & $44,55^{\mathrm{c}}$ & $45,02^{\mathrm{c}}$ \\
$\mathrm{k}_{3} \mathrm{f}_{2}$ & $25,88^{\mathrm{a}}$ & $58,50^{\mathrm{a}}$ & $58,69^{\mathrm{a}}$ \\
$\mathrm{k}_{3} \mathrm{f}_{3}$ & $21,75^{\mathrm{b}}$ & $50,85^{\mathrm{b}}$ & $51,15^{\mathrm{b}}$ \\
\hline
\end{tabular}

Keterangan : Angka-angka yang diikuti huruf yang sama menunjukkan tidak berbeda nyata berdasarkan uji BNT pada taraf $\alpha=5 \%$

Tabel 14. Rata-Rata Saat Munculnya Crops pada Perlakuan Kombinasi Jarak Tanam dan Perlakuan Pupuk Kandang Ayam

\begin{tabular}{cc}
\hline $\begin{array}{c}\text { Kombinasi } \\
\text { Perlakuan }\end{array}$ & Rata-rata saat munculnya Crops (hst) \\
\hline $\mathrm{k}_{1} \mathrm{f}_{0}$ & $23,50^{\mathrm{c}}$ \\
$\mathrm{k}_{1} \mathrm{f}_{1}$ & $22,83^{\mathrm{b}}$ \\
$\mathrm{k}_{1} \mathrm{f}_{2}$ & $22,08^{\mathrm{a}}$ \\
$\mathrm{k}_{1} \mathrm{f}_{3}$ & $22,00^{\mathrm{a}}$ \\
$\mathrm{k}_{2} \mathrm{f}_{0}$ & $23,33^{\mathrm{c}}$ \\
$\mathrm{k}_{2} \mathrm{f}_{1}$ & $22,08^{\mathrm{a}}$ \\
$\mathrm{k}_{2} \mathrm{f}_{2}$ & $22,00^{\mathrm{a}}$ \\
$\mathrm{k}_{2} \mathrm{f}_{3}$ & $22,00^{\mathrm{a}}$ \\
$\mathrm{k}_{3} \mathrm{f}_{0}$ & $22,00^{\mathrm{a}}$ \\
$\mathrm{k}_{3} \mathrm{f}_{1}$ & $23,17^{\mathrm{bc}}$ \\
$\mathrm{k}_{3} \mathrm{f}_{2}$ & $22,08^{\mathrm{a}}$ \\
$\mathrm{k}_{3} \mathrm{f}_{3}$ & $22,00^{\mathrm{a}}$ \\
\hline
\end{tabular}

Keterangan : Angka-angka yang diikuti huruf yang sama menunjukkan tidak berbeda nyata berdasarkan uji BNT pada taraf $\alpha=5 \%$ 
Tabel 15. Rata-Rata Berat Basah Crops pada Perlakuan Kombinasi Jarak Tanam dan Perlakuan Pupuk Kandang Ayam

\begin{tabular}{cc}
\hline $\begin{array}{c}\text { Kombinasi } \\
\text { Perlakuan }\end{array}$ & Rata-rata \\
\hline $\mathrm{k}_{1} \mathrm{f}_{0}$ & $0,68^{\mathrm{g}}$ \\
$\mathrm{k}_{1} \mathrm{f}_{1}$ & $0,76^{\mathrm{ef}}$ \\
$\mathrm{k}_{\mathrm{1}} \mathrm{f}_{2}$ & $0,92^{\mathrm{b}}$ \\
$\mathrm{k}_{1} \mathrm{f}_{3}$ & $0,81^{\mathrm{de}}$ \\
$\mathrm{k}_{2} \mathrm{f}_{0}$ & $0,68^{\mathrm{g}}$ \\
$\mathrm{k}_{2} \mathrm{f}_{1}$ & $0,84^{\mathrm{cd}}$ \\
$\mathrm{k}_{2} \mathrm{f}_{2}$ & $0,91^{\mathrm{bc}}$ \\
$\mathrm{k}_{2} \mathrm{f}_{3}$ & $0,93^{\mathrm{b}}$ \\
$\mathrm{k}_{3} \mathrm{f}_{0}$ & $0,71^{\mathrm{fg}}$ \\
$\mathrm{k}_{3} \mathrm{f}_{1}$ & $0,83^{\mathrm{de}}$ \\
$\mathrm{k}_{3} \mathrm{f}_{2}$ & $1,08^{\mathrm{a}}$ \\
$\mathrm{k}_{3} \mathrm{f}_{3}$ & $0,96^{\mathrm{b}}$ \\
\hline
\end{tabular}

Keterangan : Angka-angka yang diikuti huruf yang sama menunjukkan tidak berbeda nyata berdasarkan uji BNT pada taraf $\alpha=5 \%$

Hasil sidik ragam menunjukan bahwa kombinasi perlakuan jarak tanam dan dosis pupuk kandang ayam berpengaruh sangat nyata terhadap pertambahan jumlah daun umur 15,30 dan 45 HST, pertambahan diameter tajuk tanaman umur 15, 30 dan 45 HST serta pertambahan tinggi tanaman umur 30 HST. Kombinasi perlakuan jarak tanam dan dosis pupuk kandang ayam berpengaruh nyata terhadap pertambahan tinggi tanaman umur 15 dan 45 HST, saat munculnya crops serta berat basah crops. Hasil uji BNT 5\% menunjukan bahwa kombinasi perlakuan $\mathrm{k}_{2} \mathrm{f}_{2}$ \{(Jarak tanam $60 \mathrm{~cm} \mathrm{x} 60 \mathrm{~cm}$ ) ; (Dosis $2,0 \mathrm{~kg}$ pupuk kandang ayam $/ \mathrm{m}^{2}$ lahan setara dengan 20 ton/ha)\} menghasilkan pertumbuhan yang terbaik berdasarkan parameter pertambahan jumlah daun dan pertambahan diameter tajuk tanaman, pertambahan tinggi tanaman umur 30 dan 45 HST serta saat munculnya crops. Perlakuan terbaik pada kombinasi perlakuan $\mathrm{k}_{2} \mathrm{f}_{2}$ dengan rata-rata untuk parameter pertambahan jumlah daun berturut-turut adalah 5,92 helai (15 HST), 13,67 helai (30 HST) dan 16,25 helai (45 HST). Ratarata untuk parameter pertambahan diameter tajuk tanaman berturut-turut adalah $25,85 \mathrm{~cm}$ (15 HST), $57,58 \mathrm{~cm}$ (30 HST) dan $57,58 \mathrm{~cm}$ (45 HST). Rata-rata untuk parameter tinggi tanaman berturut-turut adalah $7,79 \mathrm{~cm}(30 \mathrm{HST})$ dan 15,33 $\mathrm{cm}$ (45 HST) serta untuk parameter saat munculnya crops adalah 22,00 HST. Sedangkan kombinasi perlakuan $\mathrm{k}_{3} \mathrm{f}_{2}\{($ Jarak tanam $60 \mathrm{~cm} \times$ $70 \mathrm{~cm}$ ); (Dosis 2,0 kg pupuk kandang ayam $/ \mathrm{m}^{2}$ lahan setara dengan 20 ton/ha) \} menghasilkan pertumbuhan dan produksi yang terbaik berdasarkan parameter berat basah crops yaitu

\section{KESIMPULAN}

1. Perlakuan jarak tanam berpengaruh sangat nyata pada budidaya tanaman Kubis Bunga Putih (Brassica oleracea var. botrytis L. subvar. cauliflora DC). Perlakuan terbaik pada
$1,08 \mathrm{~kg}$. Kombinasi perlakuan $\mathrm{k}_{1} \mathrm{f}_{3}\{($ Jarak tanam $60 \mathrm{~cm} \times 50 \mathrm{~cm}$ ); (Dosis 2,5 kg pupuk kandang ayam / $\mathrm{m}^{2}$ lahan setara dengan 25 ton/ha) menghasilkan pertumbuhan yang terbaik berdasarkan parameter pertambahan tinggi tanaman umur 15 HST yaitu $4,66 \mathrm{~cm}$. Kombinasi perlakuan $\mathrm{k}_{2} \mathrm{f}_{2}$ menghasilkan pertumbuhan yang terbaik diduga dengan perlakuan jarak tanam tersebut telah cukup memberikan ruang tumbuh yang memadai bagi tanaman sehingga tidak terjadi kompetisi dalam hal penggunaan sinar matahari dan unsur hara. Selain itu, dengan perlakuan dosis pupuk kandang ayam sesuai perlakuan tersebut telah mampu menyediakan unsur hara dalam jumlah yang cukup dan seimbang bagi tanaman. Dengan ruang tumbuh yang cukup untuk perkembangan akar sehingga pertumbuhan dan perkembangan akar tanaman yang satu tidak dapat masuk ke dalam sistem perakaran tanaman yang lainnya sehingga penyerapan unsur hara oleh tanaman menjadi lebih baik. Hal ini sesuai dengan pendapat pendapat Cahyono (2001) dengan pengaturan jarak tanam maka tanaman tidak dapat saling berebut dalam penggunaan zat hara karena akar tanaman yang satu tidak dapat masuk ke dalam sistem perakaran tanaman yang lainnya serta berpengaruh dalam penggunaan unsur-unsur iklim dan efisiensi dalam penggunaan tanah. Kemudian diperjelas oleh Winarso (2005), produksi tanaman baik shoot maupun root akan meningkat hingga batas tertentu sesuai dengan penambahan suplai hara / air, akan tetapi apabila suplai unsur hara / air terus meningkat hingga melebihi kebutuhan hara produksi tanaman akan turun.

$\mathrm{k}_{2}$ untuk parameter pertambahan jumlah daun dengan rata-rata berturut - turut adalah 4,52 helai (15 HST) dan 10,67 helai (30 HST) dan untuk parameter pertambahan tinggi tanaman adalah 5,64 $\mathrm{cm}$ (30 HST). 
2. Perlakuan dosis pupuk kandang ayam berpengaruh sangat nyata terhadap pertumbuhan dan produksi tanaman Kubis Bunga Putih (Brassica oleracea var. botrytis L. subvar. cauliflora DC). Perlakuan terbaik pada $\mathrm{f}_{2}$ untuk parameter pertambahan jumlah daun dengan rata-rata berturut - turut adalah 5,25 helai (15 HST), 11,53 helai (30 HST) dan 13,75 helai (45 HST), untuk parameter pertambahan tinggi tanaman dengan rata-rata berturut - turut adalah 4,11 cm (15 HST), 6,46 cm (30 HST) dan $12,99 \mathrm{~cm}$ (45 HST), parameter pertambahan diameter tajuk tanaman dengan rata-rata berturut - turut adalah $22,93 \mathrm{~cm} \quad$ (15 HST), 53,37 cm (30 HST) dan $53,43 \mathrm{~cm}$ (45 HST), parameter saat munculnya crops adalah 22,06 HST dan berat basah crops adalah $0,97 \mathrm{~kg}$.

3. Kombinasi perlakuan jarak tanam dan dosis pupuk kandang ayam berpengaruh sangat nyata terhadap pertumbuhan dan produksi tanaman Kubis Bunga Putih (Brassica oleracea var. botrytis L. subvar. cauliflora DC). Perlakuan terbaik pada $\mathrm{k}_{2} \mathrm{f}_{2}$ untuk parameter pertambahan jumlah daun dengan rata-rata berturut - turut adalah 5,92 helai (15 HST), 13,67 helai (30 HST) dan 16,25 helai (45 HST), parameter pertambahan diameter tajuk tanaman berturut-turut adalah $25,85 \mathrm{~cm}$ (15 HST), $\quad 57,58 \mathrm{~cm}(30$ HST) dan 57,58 $\mathrm{cm}$ (45 HST), parameter tinggi tanaman berturut-turut adalah $7,79 \mathrm{~cm}(30$ HST) dan $15,33 \mathrm{~cm}$ (45 HST) serta untuk parameter saat munculnya crops adalah 22,00 HST.

\section{DAFTAR PUSTAKA}

Cahyono. 2001. Kubis Bunga dan Broccoli. Kanisius. Yogyakarta.

Harjono, I. 1996. Melirik Bisnis Tani Kubis Bunga. Aneka. Solo.

Islami T. dan Utomo. 1995. Hubungan Tanah, Air dan Tanaman, IKIP Semarang Press, Semarang.

Setiawan, A. I. 2002. Memanfaatkan Kotoran Ternak. Penerbit Swadaya. Jakarta.

Sitompul, S.M. dan B. Guritno. 1995. Analisis Pertumbuhan tanaman. Gadjah Mada University Press. Yogyakarta.

Sutedjo, M.M. 1991. Pupuk dan Cara Pemupukan, Rineka Cipta, Jakarta.

Syekhfani. 2000. Arti Penting Bahan Organik Bagi Kesuburan Tanah. Konggres I dan Semiloka Nasional. MAPORINA. Batu, Malang.

Winarso, S. 2005. Kesuburan Tanah, Gava Media, Yogyakarta. 